\title{
7: 75046225-75043493
}

National Cancer Institute

\section{Source}

National Cancer Institute. 7: 75046225-75043493. NCI Thesaurus. Code C41871.

Physical location of CCL26_Gene 